\title{
Drug Resistance due to Mutation in UL 97 and Certain Other Specific Genes in Cytomegalovirus Strains: An Overview
}

\author{
Sunil Kumar and Sanjay Mishra* \\ School of Biotechnology, IFTM University, Lodhipur Rajput, Delhi Road (NH 24), Moradabad 244102, U.P., \\ India. \\ *Corresponding Author: sanjaymishra@iftmuniversity.ac.in
}

\begin{abstract}
The study of human cytomegalovirus (HCMV) antiviral drug resistance has enhanced knowledge of the virological targets and the mechanisms of antiviral activity. The currently approved drugs, ganciclovir $(G C V)$, foscarnet (FOS), and cidofovir (CDV), target the viral DNA polymerase. The widespread use of ganciclovir $(G C V)$ to treat cytomegalovirus $(C M V)$ infections in immuno-suppressed patients has led to the development of drug resistance.GCV anabolism also requires phosphorylation by the virus-encoded UL97 kinase. GCV resistance mutations have been identified in both genes, while FOS and CDV mutations occur only in the DNA polymerase gene. Confirmation of resistance mutations requires genotypic assays based on sequencing provide more rapid results but are dependent on prior validation by phenotypic methods. Recombinant phenotyping methods performed in a few research laboratories have resolved some of the conflicting results. Treatment options for drug-resistant HCMV infections are complex and have not been subjected to controlled clinical trials, although consensus guidelines have been proposed.
\end{abstract}

Keywords: Cytomegalovirus, antiviral activity, drug-resistance, ganciclovir, foscarnet, cidofovir, viral DNA polymerase.

\section{Introduction}

Cytomegalovirus(from the Greek cyto-, "cell", and -megalo-, "large") is a viral genus of the viral family known as Herpesviridae or herpesviruses. It is typically abbreviated as CMV. The species that infects humans is commonly known as human CMV (HCMV) or human herpesvirus-5 (HHV-5), and is the most studied of all cytomegaloviruses (Ryan and Ray, 2004). Within Herpesviridae, CMV belongs to the Betaherpesvirinae subfamily, which also includes the genera Muromegalovirus and Roseolovirus (HHV-6 and HHV-7) (Koichi et al., 2007). It is related to other herpesviruses within the subfamilies of Alphaherpesvirinae that includes herpes simplex viruses (HSV)-1 and -2 and varicella-zoster virus (VZV), and the Gammaherpesvirinae subfamily that includes Epstein-Barr virus (Ryan and Ray 2004). All herpesviruses share a characteristic ability to remain latent within the body over long periods. Although they may be found throughout the body, CMV infections are frequently associated with the salivary glands in humans and other mammals (Koichiet al., 2007). Other CMV viruses are found in several mammal species, but species isolated from animals differ from HCMV in terms of genomic structure, and have not been reported to cause human disease.HCMV is strictly species specific, as are the other cytomegalovirus.

CMV was derived from the observation of a characteristic swollen or "cytomegalic" appearance of cells first noted in infants who died of various causesand is a common viral cause of congenital defects and becomes particularly prominent as a pathogen in immunocompromised patients, mental retardation and nonhereditary sensorimeural deafness in children (Porath et al., 1990). It also is a significant cause of transfusion acquired infections and is perhaps the most infection that occurs in transplant recipients and those with acquired immune deficiency syndrome (AIDS) (Weller et al., 1993).

CMV is associated with leukocytes and may be transmitted with a blood transfusion (Lerner and Sampliner, 1977) or transplanted organ (Ho et al., 1975). HCMV infection causes by reactivation of the latent virus months or years later. Primary infection with HCMV is usually not diagnosed, because it is asymptomatic or associated with a mild influenza like illness in the normal host. Symptomatic primary HCMV may occur in surgical patients who acquire the virus from blood transfusion and it is one of the causes of the post cardiotomy syndrome after open-heart surgery. The second major clinical problem caused by HCMV is congenital or intrauterine infection, estimated at 1:100 infants by viral isolation from urine at birth. Congenital infection is classically associated with hepatosplenomegaly, thrombocytopenia, hemolytic anemia, chorioretinitis and encephalitis (Porath et al., 1990). In children and adults symptomatic CMV infection is characterized by fever, heterophile agglutinin- negative mononucleosis, and subclinical hepatitis (Klemola et al., 1970). Although CMV infection is quite common, CMV disease is rare. The majority of infection is asymptomatic. In symptomatic infection, the clinical manifestations vary with the age of the affected individual, and the severity ranges from mild to fetal illness. A variety clinical syndromes resulting from involvement of various organs are being 
increasingly recognized and reported. Examples are neonatal infection, mononucleosis, post perfusion syndrome, hepatitis, pneumonia, chorioretinitis, conjunctivitis and other ocular manifestation, gastrointestinal syndromes, meningoencephalitis, polyneuritis, thrombocytopenic purpura, hemolytic anemia, vasculitis, carditis, arthritis, cystitis, nephritis and periodontitis (Naraqi, 1991).

Recent studies have implicated mammalian viruses in the pathogenesis of human periodontitis (Contreras and Slots, 1996; Parra and Slots, 1996). HCMV is frequently detected in human periodontitis lesion. However, no information is available on the types of gingival cells infected by herpes viruses. Gingivitis is usually a precursor to periodontitis but not all gingivitis progresses to periodontitis. Periodontitis result from a host response to microbial plaque; however, mechanisms for its initiation and progression are still being studies. Periodontitis have four major types included: adult, early-onset (prepuberal), refractory (Juvenile), and periodontitis associated with systemic diseases. HCMV in the pathogenesis of human periodontitis can infect a variety of inflammatory cells. It is important to determine which inflammatory cells of the periodontium harbor herpes viruses. A significantly higher prevalence of HCMV was detected in the gingival cervicular fluid of advanced periodontitis patients than that of gingivitis patients (Parra and Slots, 1996) and in deep periodontal pockets compared with shallow periodontal sites within individual adult periodontitis patients (Contreras and Slots, 1996). Periodontal breakdown in children is often associated with some fault in host response (as in Down' Syndrome), but early destructive periodontal disease i.e. Juvenile periodontitis (JP), has been reported by Cogen et al. (1992) in healthy Alabama children. Periodontitis in adults, there is considerable paleontological evidence of periodontal disease in early humans, and past epidemiological studies have emphasized the general prevalence of the disease.

\section{Human Cytomegalovirus}

\section{- Virus structure and genome organization}

HCMV has a linear double-stranded DNA genome of approximately $230 \mathrm{kbp}$ encoding more than 200 proteins. The virion, which is $150-200 \mathrm{~nm}$ in diameter, consists of an icosahedral capsid surrounded by a tegument or matrix, which is further surrounded by a lipid-protein envelope. The viral genome is divided into two unique components, unique long (UL) and unique short (US) regions. The unique regions are flanked by terminal (TR) and inverted repeat (IR) sequences, UL by TRL and IRL, and US by IRS and TRS, respectively. DNA sequence based analyses demonstrate a great genomic heterogeneity within HCMV worldwide. The capsid of the virion is composed of seven proteins. The major (MCP) and minor capsid proteins (mCP) are encoded by UL86 and UL85, respectively. The minor capsid binding protein (mC-BP) is encoded by UL46 and the smallest capsid protein (SCP) by UL48.5. Three assemblin protein-related proteins associate with capsids and are the products of UL80, UL80a and UL80.5 genes. A tegument contains at least 25 proteins, of which many are phosphorylated. The basic phosphoprotein (pp150) encoded by UL32 and lower matrix protein (pp65) encoded by UL83, are the most abundant proteins expressed during virus replication. The other prominent tegument proteins are ppUL99 (pp28), ppUL82 (pp71) and ppUL48 (huge tegument protein). Several transcriptional transactivator proteins have also been localized to the tegument. The envelope consists of two prominent glycoprotein complexes, a complex of dimers of glycoprotein B (gB), encoded by UL55, and a complex of the $\mathrm{gH}$, gL, and gO, encoded by UL75, UL115 and UL74, respectively. These glycoprotein complexes are assumed to play an important role in virus entry.

\section{- Virus replication}

HCMV exhibits a restricted host range in cell culture. Although in vitro the most commonly used cells are primary differentiated human fibroblasts derived from skin or lung, HCMV can also replicate in other cell types including endothelial and epithelial cells, smooth muscle cells and leukocytes (Sinzger and Jahn, 1996). After the attachment of the virus to the cell surface, fusion of the virion envelope and the cell membrane occurs (Mocarski and Courcelle, 2001). The cellular receptors for HCMV are still unclear, but it has been suggested to be widely distributed in cells (Mocarski and Courcelle, 2001). Epidermal growth factor receptor has recently been suggested to serve as a receptor for HCMV (Wang et al., 2003). The virus capsid is rapidly transported to the cell nucleus and, after the proteolysis of the capsid proteins; the viral DNA is released into the nucleus.

DNA replication, formation of capsid and packaging of viral DNA occur in the nucleus. Subsequently, nucleocapsids acquire a primary envelopment by budding at the nuclear membrane. They further mature through a de-envelopment/re-envelopment process in the cytoplasm before leaving the cell via an exocytic like pathway (Mettenleiter, 2002; Mocarski and Courcelle, 2001). The whole replication cycle of human CMV is slow, requiring approximately 48-72 hours. The cytopathic effect in response to HCMV is characteristically cell enlargement with intranuclear inclusions. 


\section{Pathogenesis}

It has been suggested that epithelial cells of the upper alimentary, respiratory and genito- urinary tracts can be the site of primary replication after the direct contact of infectious virus and mucosal surface (Pass, 2001). In addition, it has been suggested that a fetus can be infected hematogenously (Halwachs-Baumann et al., 1998; Hemmings et al., 1998). In any case, once HCMV infection is established, leukocyte-associated and endothelial cell-associated viremia appears to play an important role in the passage of the virus between the various tissues of the host. Viremia may last for several weeks during the primary infection. Hematogenous spreading typically results in the infection of ductal epithelial cells at the initial site. HCMV can infect a wide range of tissues including salivary glands, gastrointestinal tract, lung, liver, brain, kidney, spleen, pancreas, eye, heart, adrenals, thyroid and genital tract and then replicate in diverse cell types, including fibroblasts, epithelial cells, macrophages, vascular smooth muscle and endothelial cells. HCMV is also suggested to infect the vascular wall and play a role in the development of atherosclerosis.

In immunocompetent individuals, primary infection (and also reactivation/reinfection) usually remains asymptomatic or results in benign clinical symptoms such as fever, elevated levels of transaminases and/or mononucleosis syndrome. Severe clinical symptoms are observed in congenital infections and among immunocompromised patients (such as transplant recipients and AIDS-patients)(Griffiths and Emery, 1997), in whom HCMV infections are an important factor for developing HCMV-associated disease.

\section{Epidemiology and transmission}

HCMV infects humans of all ages. Acquisition of the virus in the general population usually occurs early in life, mainly during the first two decades, and often already during the first year. Based on seroepidemiological studies, the seroprevalence varies between $30 \%$ to $100 \%$ in different countries. The great seroprevalence and also early acquisition of the virus have been associated with lower socioeconomic circumstances, developing countries and countries with crowded populations (Ho, 1990). However, in Scandinavian countries seroprevalence is as high as 60-80\%, and in Finland even 70-80\%, despite good hygiene and a high socioeconomic level.

After the primary infection, which is usually asymptomatic or very mild in immunocompetent individuals, the virus will remain in a lifelong latent state in the host. Later in life, the virus can reactivate or an individual can have a reinfection. Transmission of the virus can occur vertically from mother to fetus or newborn, or horizontally from one individual to another (Griffiths and Emery, 1997). During primary infection, the virus is secreted into the urine, saliva, semen and cervical secretions for weeks to months, as well as intermittently during reactivations and reinfection. Vertical transmission can occur transplacentally or prenatally. An intra-uterine infection is the result of maternal viremia and prenatally acquired infection can occur at the time of delivery from infected maternal genital secretions or later via breast milk. Later in life, infection usually occurs by close contact via infected bodily fluids, e.g. from child to child or from child to susceptible adult via saliva or urine. In the adult population, a major route of infection is sexual transmission. HCMV can also be transmitted by blood transfusions or by organ or bone marrow transplantations.

\section{Laboratory Diagnosis of HCMV}

An accurate and rapid diagnosis of HCMV in transplant patients is of utmost importance. Different laboratory methods based on either serology or identification of virus/virus components in clinical specimens are now available. However, in recent years PCR methods, especially with quantitative modifications of PCR, and also with other nucleic acid amplification techniques are well authenticated and established.

\section{- Histological methods}

Traditionally the recognition of cytomegalic inclusion bodies in histological specimens has been used for the diagnosis. In organ specific HCMV infection, such as HCMV pneumonitis or hepatitis, characteristic viral inclusions may be seen. The large inclusions are intranuclear and have a characteristic owl-eye appearance in haematoxylin and eosin stained tissue specimens. The positive results correlate well with active HCMV infection of the organ, e. g. hepatitis, but the sensitivity of the histopathological finding is relatively low (Colina et al., 1995; Paya et al., 1989). Immunostaining with specific polyclonal or monoclonal antibodies against HCMV antigens has increased the sensitivity of the method compared to conventional staining (Barkholt et al., 1994; Colina et al., 1995; Paya et al., 1990).

However, false-negative results may occur because of the focal and scarce distribution of HCMV positive cells in tissue samples (Colina et al., 1995). ISH methods, described for the identification of viral DNA in infected cells, have also been employed to improve the histological diagnosis of infection (Barkholt et al., 1994; Colina et al., 1995; Einsele et al., 1989; Espy et al., 1991; Musiani et al., 1996; Paya et al., 1990). HCMV specific probe, usually labeled by biotin, is used in these assays. Although the histological methods may have an important role in detecting HCMV organ involvement, they are not suitable for the early diagnosis of HCMV 
infection. In addition, these assays are very laborious, and biopsy specimens are only taken when an end-organ disease is suspected.

○ Serology

Humeral response to primary HCMV infection is manifested by the production of IgG and IgM antibodies. Thus a diagnosis of HCMV infection can be obtained indirectly through serology. A variety of laboratory tests with different degrees of sensitivity have been described for the measurement of HCMV antibodies in human sera. The methods include complement fixation, indirect hemagglutination, latex agglutination, radioimmunoassay, immunofluorescence and enzyme immunoassay (Mendez et al., 1999a; Sia and Patel, 2000). In enzyme-linked immunosorbent (ELISA) assays many different antigens have successfully been used as targets for detecting specific antibody production (Monte et al., 1996).

\section{- Viral culture}

Infectious virus can be isolated from various clinical materials, such as bodily secretions, tissue or peripheral blood, in cell cultures which are permissive for HCMV replication. Human fibroblast cell cultures, obtained from the foreskin or from the embryonic lung tissues, have been used for conventional and shell vial methods for the isolation of HCMV (Mendez et al., 1999a). In conventional viral isolation methods, commonly used in earlier times, determination of viral replication is based on typical cytopathic effects (CPE) produced by HCMV. The time required for the development of CPE usually varies from 2 to 4 weeks, even up to six weeks.

Several less time-consuming methods have been developed for the isolation of infectious virus (Mendez et al., 1999a; Sia and Patel, 2000). One of the most commonly used rapid methods is the shell vial culture (Gleaves et al., 1984). In this method, for the improvement of absorption of the virus, the specimen is centrifuged onto the cell culture. Fibroblasts monolayer cultured in vials containing cover slips are used. These shell vial culture methods utilize indirect immunofluorescence to detect the immediate-early (IE) viral antigen after incubation of culture for one to three days (Lautenschlager et al., 1989). The isolation of HCMV from the blood or target organ specimen by cell culture methods has a high correlation with disease. However, the relatively low sensitivity of detection of the virus in blood samples compared to nucleic acid-based and antigenemia methods, limits the use of these assays in the diagnosis and monitoring of HCMV infection in transplant patients (Badley et al., 1996; Evans et al., 1999; Van der Bij et al., 1988; Wirgart et al., 1996).

\section{$\circ$ Antigen detection}

The antigenemia assay has been a major advance in the diagnosis of HCMV infection in transplant patients. In this test, monoclonal antibodies to pp65 (UL83) (Depto and Stenberg, 1989; Gerna et al., 1992; Grefte et al., 1992), the lower matrix protein, are used for the direct immunostaining of blood polymorphonuclear leukocytes (PMNL). However, it has been shown that the pp65 antigen in PMNLs is not a direct indication of virus replication in vivo, since the virus and viral material detected in PMNLs are transferred from other infected cells, e.g. endothelial cells, mainly by microfusion events (Gerna et al., 2000). Nevertheless, the pp65 antigenemia assay has been successfully used in the diagnosis of HCMV in transplant patients since the late 1980's.

The antigenemia assay is more sensitive than cell culture methods in detecting HCMV in the blood (Landry and Ferguson, 1993; van den Berg et al., 1991; Van der Bij et al., 1988). It is also highly specific for HCMV but a positive result does not always predict the onset of symptomatic infection (Landry and Ferguson, 1993; Sia and Patel, 2000; Tanabe et al., 1997). Nevertheless, when using the test in a quantitative manner, the assay can be used to predict and diagnose HCMV infection: at least, a higher degree of antigenemia is correlated with symptomatic disease, as has been shown by many groups (Hadaya et al., 2003; Humar et al., 1999; Kim et al., 2003).

One disadvantage of the antigenemia assay is that the blood samples should be processed within a certain time, preferably within six hours, for optimal results (Schafer et al., 1997). In addition, though there have been attempts to simplify the method (Gratacap-Cavallier et al., 2003; Ho et al., 1998), it is still quite timeconsuming and laborious, at least with large specimen numbers. The automation of the test is also difficult because of the number of steps and the subjective evaluation of the infected leukocytes. Although there have been attempts to standardize the assay (Gerna et al., 1998; The et al., 1995; Verschuuren et al., 1999), there are a number of various in-house and commercial modifications available. This makes comparison of the results between different centers difficult. The clinically significant threshold of the number of positive leukocytes seems to vary also among different types of transplant populations (Baldanti et al., 1998; Razonable et al., 2002b; Sia and Patel, 2000). In any case, the pp65 antigenemia test has shown its clinical utility in the diagnosis of HCMV infection, in guiding of pre-emptive therapy, and also in the monitoring of response to antiviral treatment (Baldanti et al., 1998; Grossi et al., 1996; Kim et al., 2003; Kusne et al., 1999). 


\section{- Nucleic acid amplification methods}

The widespread introduction of the application of nucleic acid amplification technologieshas been the most important improvement in HCMV diagnostics in the past decade. The most frequently used methods are based on PCR detecting HCMV DNA (or RNA) in whole blood or in different blood compartments. Both qualitative and quantitative assays have been used. However, understanding of the correlation between viral loads and clinical symptoms has diminished the significance of qualitative methods. Different kind of quantitative PCR assays, both in-house and commercial ones, have been employed. The in-house assays, based on competitive PCR, are usually technically complicated. Commercial and real-time based applications, which are more convenient and faster, are more widely used at present. Also other nucleic acid-based techniques, such as nucleic acid sequence based amplification (NASBA) and signal amplification (Hybrid Capture System) have successfully been used in the detection of viral mRNA or DNA, respectively.

\section{$\circ \quad$ Other nucleic acid amplification methods}

It has been suggested that the detection of HCMV mRNA would correlate better with symptomatic HCMV infection than DNA, because of the ability of the virus to remain latent in the host cell. Previously, in-house RTPCR methods were used for the detection of mainly immediate early or late transcripts in blood samples of transplant patients (Bitsch et al., 1993; Gaeta et al., 1997; Nelson et al., 1996). The sensitivities, specificities and correlations with HCMV disease of these tests varied considerably. Later, many applications based on NASBA technique have been employed. NASBA is an isothermal amplification process which involves the coordinated activities of three different enzymes: ribonuclease $\mathrm{H}$, reverse transcriptase and DNA-dependent RNA polymerase (Compton, 1991). The final product of the process is a specific singlestranded RNA, instead of the dsDNA of PCR. The high sensitivity in detecting HCMV infection has been shown by the NASBA assay with the IE-1 target (Blok et al., 1999; Blok et al., 2000; Goossens et al., 1999; Oldenburg et al., 2000). In recent years, many applications of the NASBA technique based on the detection of pp67 mRNA have been developed and the test application is also commercially available (Gerna et al., 2003; Witt et al., 2000). These assays detect pp67 mRNA, which is transcribed late in the viral replicative cycle, in a qualitative manner. pp67 NASBA assay may have a clinical utility in both early diagnosis of symptomatic HCMV infection and monitoring transplant patients with active disease, as well as in guiding pre-emptive therapy (Caliendo et al., 2002; Gerna et al., 2003; Witt et al., 2000). Recently, the pp67 NASBA has also been combined with the quantitative detection of IE-1 mRNA, which may improve the clinical utility of this technique (Greijer et al., 2002).

HCMV DNA has also been detected by a signal amplification method, Hybrid Capture System, from blood samples of transplant patients (Aitken et al., 1999; Bhorade et al., 2001; Ho et al., 2000; Mazzulli et al., 1999; Norris et al., 2002). The Hybrid Capture System is a solution hybridization assay that involves amplified detection instead of amplification of the desired nucleic acid fragment. The assay uses a specific RNA probe which targets $17 \%$ of the HCMV genome. The RNA-DNA hybrid is captured by a monoclonal antibody and is detected by a luminometer. Both qualitative and quantitative applications are commercially available. The quantitative form has clinical utility in the diagnosis and monitoring of HCMV infection (Aitken et al., 1999; Bhorade et al., 2001; Ho et al., 2000; Norris et al., 2002).

\section{$\circ$ Antiviral susceptibility testing}

After the more widespread use of antiviral drugs, resistant HCMV strains havebeen reported also in the transplant patient population (Isada et al., 2002; Limaye, 2002; Lurain et al., 2002). The methods used for antiviral susceptibility testing can be divided into phenotypic and genotypic assays. Phenotypic assays rely on the suppression of viral growth in the presence of antiviral agents. Various modifications have been employed (McSharry et al., 1998) of which the plaque reduction assay is considered as a standard method. A major limiting factor of the phenotypic method is that they require viral culture from the clinical sample, followed by several passages to reach the necessary viral titers for the performance of the assay, which can take up 4-6 weeks. Because the assay is burdensome and it lacks standardization, it is not routinely undertaken in the majority of centers. The facts, that specific mutations in the UL97 and UL54 genes are associated with antiviral drug resistance, have led to the development of genetic methods. These are based on PCR amplification of the specific region of the genome followed by restriction enzyme analysis or direct sequencing of the amplification product/products (Alain et al., 1997; Lurain et al., 2002; Mendez et al., 1999b; Wolf et al., 1995). An obvious advantage of these assays is the possibility to use clinical specimens directly, rather than virus isolates, which significantly shortens the time required for performance of the test. In addition, mixtures of the different strains are not always detected in viral culture methods (Lurain et al., 2002). However, standardization and validation of these methods are needed for clinical use. 


\section{Treatment of the disease}

The three antiviral drugs that are currently licensed for the treatment of HCMV infection are ganciclovir (GCV), foscarnet and cidofovir. Ganciclovir is the drug of choice in the treatment of symptomatic infections. Ganciclovir is a specific nucleoside analog which first is phosphorylated before it gains antiviral activity (Littler et al., 1992; Sullivan et al., 1992). The initial phosphorylation is mediated by virus encoded phosphotransferase (product of UL97). The monophosphate form is further phosphorylated by the host's cellular kinases into the active triphosphate form, which inhibits viral DNA polymerase by competing with deoxyguanosine triphosphate (Noble and Faulds, 1998). For the treatment of HCMV disease, ganciclovir is administered intravenously (i.v.) for at least two weeks.

Intravenous foscarnet may be used under conditions of failure of ganciclovir treatment, ganciclovir resistance, or excessive side effects, such as leukopenia (Crumpacker, 1996; Noble and Faulds, 1998). Foscarnet is an inorganic pyrophosphate analog and directly inhibits viral DNA polymerase (Chrisp and Clissold, 1991; Crumpacker, 1992). However, foscarnet is nephrotoxic, which limits its use in kidney transplantation. Intravenous cidofovir may also be used, but experience of this agent in solid organ recipients is still very limited. Cidofovir is a cytosine analog which does not require the virus encoded phosphotransferase activity. Instead host cellular enzymes carry out the phosphorylations needed for activation (Lalezari et al., 1995; Snoeck et al, 1988).

Valganciclovir, a pro-drug of ganciclovir, is a new promising compound which is administered orally and has an increased bioavailability compared to that of oral ganciclovir (Pescovitz et al., 2000). Nowadays valganciclovir is used in therapy of HCMV disease. However, more clinical trials are needed. The HCMV hyperimmunoglobulin may also be used in some patient groups in combination with antiviral drugs, e.g. lung transplant patients with HCMV pneumonia (Patel and Paya, 1999; Zamora, 2001).

Two different strategies, prophylaxis and pre-emptive therapy, are used for the prevention of symptomatic HCMV infection after transplantation. In prophylaxis, antiviral drugs are administered before any evidence of the virus, and in pre-emptive therapy, antiviral drugs are administered when there is laboratory evidence of active but asymptomatic infection. The antiviral strategies for treatment and prevention of HCMV disease are outlined in more detail below.

\section{Prophylaxis}

Prophylaxis consists of administration of antiviral drugs, immediately after transplantation, either to all transplant recipients or only to those who are at the highest risk for the HCMV disease, such as seronegative recipients receiving seropositive organ or patients who are treated with anti-T-lymphocyte antibodies. The practice and guidelines for prophylactic therapy vary widely, depending on the patient population and the transplant center (Batiuk et al., 2002; Patel et al., 1996). Also hyperimmunoglobulin in combination with ganciclovir has been used in certain patient groups, e.g. lung transplant recipients (Weill et al., 2003).

The first antiviral drug used for prophylaxis was high-dose oral acyclovir, an analog of deoxyguanosine. The efficacy of oral acyclovir has been demonstrated in studies showing reductions in the incidence of HCMV disease compared with no treatment (Balfour et al., 1989; Couchoud et al., 1998; Mollison et al., 1993). A pro-drug of acyclovir, valacyclovir, has been found to be more effective than acyclovir for prevention of HCMV disease (Fiddianet al., 2002; Lowance et al., 1999). Valacyclovir has increased oral bioavailability compared to that of acyclovir (Weller et al., 1993), and in vivo it is first converted to acyclovir. The action of acyclovir (valacyclovir) is dependent on phosphorylation, in which thymidine kinase is important. However, CMV does not encode this kinase (unlike herpes simplex and varicella zoster viruses), and the phosphorylation, which may be allowed by UL97 product (Talarico et al., 1999) is less specific. For this reason, these drugs are not potent enough for the treatment of HCMV infection.

Currently, the most widely used and specific drug for HCMV prophylaxis is ganciclovir, administered orally or intravenously. Intravenous ganciclovir has been proven to be a potent prophylactic agent in many studies (Merigan et al., 1992; Paya, 2001; Winston et al., 1995). The availability of the oral form has increased the use of this agent (Speich et al., 1999; Winston and Busuttil2004; Yango et al., 2003), although the bioavailability of oral ganciclovir is lower when compared to that of intravenous ganciclovir. A pro-drug of ganciclovir, valganciclovir, is a new promising option also for prophylaxis. The drug is effectively absorbed and it is nowadays widely used although the published reports are still limited (Lake, 2003; Paya et al., 2004).

\section{Pre-emptive therapy}

In pre-emptive therapy only patients who have laboratory evidence of an active HCMV infection are treated with antiviral drugs. Therefore, the diagnostic test should predict impending symptomatic infection sufficiently early. In addition, because pre-emptive therapy requires frequent surveillance of all patients, the test should also be specific as well as rapid and easy to perform. Since viral load has been shown to be a major factor in the pathogenesis of HCMV (Emery, 1999; Hassan-Walker et al., 1999), quantitative measurements 
have been considered to have greater clinical value in a pre-emptive therapy strategy. Various diagnostic methods, virological and/or DNA/ RNA-based, may be used for this purpose (Daly et al., 2002; Gerna et al., 2003; Grossi et al., 1996; Sia and Patel, 2000; Sagedal et al, 2003).

\section{Drug resistance}

The initial studies of resistant laboratory and clinical CMV strains related ganciclovir resistance to inadequate intracellular phosphorylation of the compound in cells infected with ganciclovir-resistant viruses. Although experimental evidence at that time suggested that ganciclovir phosphorylation was controlled by a CMV-encoded function, the mechanism by which ganciclovir is phosphorylated in CMV-infected cells remained unresolved until 1992. In that year, two independent groups of investigators provided biochemical, immunological, and genetic evidence that the phosphorylation of ganciclovir in CMV-infected cells is controlled by a protein kinase homologue encoded by the UL97 open reading frame of the virus (Littler et. al., 1992, Sullivan et. al., 1992). In one study, a recombinant protein (UL97tr) was obtained by cloning a truncated part of the CMV UL97 open reading frame including sequences homologous to the catalytic domains of protein kinases into an expression vector. This protein was used to produce specific antiserum that were shown by Western blotting to react with UL97tr itself and with a protein obtained from CMV-infected cells that had a molecular weight similar to that predicted for UL97. In addition, extracts from bacteria expressing UL97tr efficiently phosphorylated ganciclovir compared with controls. Furthermore, this phosphorylating activity was neutralized by CMV seropositive serum but not by CMV seronegative serum (Littler et. al., 1992). In another study, recombinant viruses containing fragments representing the complete UL97 sequence of the ganciclovirresistant laboratory strain $759^{\mathrm{r}} \mathrm{D} 100$ prepared in marker transfer experiments were resistant to ganciclovir and unable to induce phosphorylation of ganciclovir in infected cells. Analysis of the DNA sequence of these recombinant viruses revealed a 12-bp deletion of UL97 codons 590 to 593, which resulted in a 4-amino-acid deletion (Ala-Ala-Cys-Arg) in a conserved region of the UL97 protein possibly implicated in substrate recognition (Sullivan et. al., 1992). On the basis of these results, it was proposed that UL97 is responsible for the initial phosphorylation of ganciclovir in CMV-infected cells.

These findings prompted the characterization of UL97 sequences in ganciclovir-resistant laboratory and clinical CMV strains. In one study, plaque-purified ganciclovir-resistant strains D1/3/4, D6/3/1, and D10/3/2 were obtained after sequential passages of the susceptible strain, AD169, in increasing concentrations of ganciclovir (Lurain et. al., 1994). Cells infected with these ganciclovir-resistant viruses showed reduced levels of ganciclovir phosphorylation, suggesting the presence of mutations in the UL97 region of these viruses. Sequencing studies of this open reading frame demonstrated the same mutation (ATG to ATT), resulting in a methionine to isoleucine amino acid change at amino acid residue 460 (M460I mutation) of the UL97 protein in all three resistant strains (Lurain et. al., 1994). A recombinant virus (R6HS) prepared after transfection of UL97 sequences from D6/3/1 into cells infected with AD169 was also resistant to ganciclovir and induced ganciclovir phosphorylation levels that were more than 10-fold lower than those in AD169-infected cells (Lurain et. al., 1994).

The occurrences of antiviral drug resistant HCMV strains have been documented also among organ transplant patients (Isada et al., 2002; Limaye, 2002; Lurain et al., 2002). The major risk factors for drug resistance include the long duration of drug exposure and high amounts of viral load (Chou, 2001; Drew, 2000). These factors are most prevalent in patients with primary infection, i.e. in D+/R- population, in which resistance has most often been observed (Rosen et al., 1997). The mutations in both the viral phosphotransferase gene (UL97) and the viral polymerase gene (UL54) may confer antiviral drug resistance in HCMV. The mutations of the UL97 coding sequence, which may confer resistance only to ganciclovir, occur mainly in the region including codons 460-607 (Chou et al., 1995; Hanson et al., 1995; Lurain et al., 1994). The more rare mutations in the UL54 coding sequence may confer resistance to any or all of the three most commonly used drugs (ganciclovir, foscarnet or cidofovir) (Cihlar et al., 1998b; Mousavi-Jazi et al., 2003). Mutations in UL54 appear to occur in regions between codons 300 and 1000, and they are often accompanied by mutations in UL97, showing higher levels of resistance to ganciclovir with possible cross-resistance to foscarnet and/or cidofovir (Jabs et al., 2001).

Wellcharacterized(canonical) mutations in UL97 are found inGCV-resistant clinical strains, with one of the seven mutationsM460V/I, H520Q, C592G, A594V, L595S, and C603W encountered in close to $90 \%$ of cases. Other UL97 mutationsconfer various degrees of GCV resistance, while mutations inthe UL54 DNA polymerase gene sometimes evolve to increaseresistance to GCV and confer cross-resistance to cidofovirand/or foscarnet (Lurain, N. S., and S. Chou.,2010). 


\section{Conclusion}

Resistance of CMV to antiviral agents is a well-documented complication of long-term antiviral therapy. This problem has been observed mostly in patients with AIDS and CMV retinitis in whom drugresistant CMV infections have been associated with clinical progression and therapeutic failure. Current data suggest that the incidence of infections caused by drug-resistant CMV in bone marrow or solid-organ transplant recipients is low. Because of the routine use of antiviral agents for prophylaxis or pre-emptive therapy for CMV infections in bone marrow or solid-organ transplant recipients, surveillance antiviral susceptibility studies of CMV isolates from patients developing active CMV infections would be appropriate. CMV resistance studies have been limited by the difficulty and lack of standardization of antiviral susceptibility assays.

In contrast, significant advances have been made in recent years in understanding the mechanisms by which CMV becomes resistant to antiviral agents. The recognition that specific mutations in the UL97 and UL54 genes of CMV are associated with different antiviral susceptibility patterns has prompted the development of molecular laboratory methods for detection of mutant viral sequences in viral isolates and directly in clinical specimens.

\section{References}

[1]. Aitken, C., Barrett-Muir, W., Millar, C., Templeton, K., Thomas, J., Sheridan, F., Jeffries, D., Yaqoob, M., and Breuer, J. (1999): Use of molecular assays in diagnosis and monitoring of cytomegalovirus disease following renal transplantation. J ClinMicrobiol 37, 2804-7.

[2]. Alain, S., Honderlick, P., Grenet, D., Stern, M., Vadam, C., Sanson-Le Pors, M. J., and Mazeron, M. C. (1997): Failure of ganciclovir treatment associated with selection of a ganciclovir-resistant cytomegalovirus strain in a lung transplant recipient. Transplantation 63, 1533-6.

[3]. Badley, A. D., Patel, R., Portela, D. F., Harmsen, W. S., Smith, T. F., Ilstrup, D. M., Steers, J. L., Wiesner, R. H., and Pa ya, C. V. (1996): Prognostic significance and risk factors of untreated cytomegalovirus viremia in liver transplant recipients. J Infect Dis $173,446-9$.

[4]. Baldanti, F., Revello, M. G., Percivalle, E., and Gerna, G. (1998): Use of the human cytomegalovirus (HCMV) antigenemia assay for diagnosis and monitoring of HCMV infections and detection of antiviral drug resistance in the immunocompromised. $\mathrm{J}$ ClinVirol 11, 51-60.

[5]. Balfour, H. H., Jr., Chace, B. A., Stapleton, J. T., Simmons, R. L., and Fryd, D. S. (1989): A randomized, placebo-controlled trial of oral acyclovir for the prevention of cytomegalovirus disease in recipients of renal allografts. N Engl J Med 320, $1381-7$.

[6]. Barkholt, L. M., Ehrnst, A., and Veress, B. (1994): Clinical use of immunohistopathologic methods for the diagnosis of cytomegalovirus hepatitis in human liver allograft biopsy specimens. Scand J Gastroenterol 29, 553-60.

[7]. Batiuk, T. D., Bodziak, K. A., and Goldman, M. (2002): Infectious disease prophylaxis in renal transplant patients: A survey of US transplant centers. Clin Transplant 16, 1-8.

[8]. Bhorade, S. M., Sandesara, C., Garrity, E. R., Vigneswaran, W. T., Norwick, L., Alkan, S., Husain, A. N., McCabe, M. A., and Yeldandi, V. (2001): Quantification of cytomegalovirus (CMV) viral load by the hybrid capture assay allows for early detection of CMV disease in lung transplant recipients. J Heart Lung Transplant 20, 928-34.

[9]. Bitsch, A., Kirchner, H., Dupke, R., and Bein, G. (1993): Cytomegalovirus transcripts in peripheral blood leukocytes of actively infected transplant patients detected by reverse transcription-polymerase chain reaction. J Infect Dis 167, 740-3.

[10]. Blok, M. J., Christiaans, M. H., Goossens, V. J., van Hooff, J. P., Sillekens, P., Middeldorp, J. M., and Bruggeman, C. A. (1999): Early detection of human cytomegalovirus infection after kidney transplantation by nucleic acid sequence-based amplification. Transplantation 67, 1274-7.

[11]. Blok, M. J., Lautenschlager, I., Goossens, V. J., Middeldorp, J. M., Vink, C., Hockerstedt, K., and Bruggeman, C. A. (2000): Diagnostic implications of human cytomegalovirus immediate early-1 and pp67 mRNA detection in whole-blood samples from liver transplant patients using nucleic acid sequence-based amplification.J ClinMicrobiol 38(12), 4485-91.

[12]. Caliendo, A. M., St George, K., Allega, J., Bullotta, A. C., Gilbane, L., and Rinaldo, C. R. (2002): Distinguishing cytomegalovirus (CMV) infection and disease with CMV nucleic acid assays. J ClinMicrobiol 40, 1581 -6.

[13]. Chou, S. W. (2001): Cytomegalovirus drug resistance and clinical implications. Transpl Infect Dis 3 Suppl 2, 20-4.

[14]. Chou, S., Guentzel, S., Michels, K. R., Miner, R. C., and Drew, W. L. (1995): Frequency of UL97 phosphotransferase mutations related to ganciclovir resistance in clinical cytomegalovirus isolates. J Infect Dis 172, 239-42.

[15]. Chrisp, P., and Clissold, S. P. (1991): Foscarnet. A review of its antiviral activity, harmacokinetic properties and therapeutic use in immunocompromised patients with cytomegalovirus retinitis. Drugs 41, 104-29.

[16]. Cihlar, T., Fuller, M. D., Mulato, A. S., and Cherrington, J. M. (1998b): A point mutation in the human cytomegalovirus DNA polymerase gene selected in vitro by cidofovir confers a slow replication phenotype in cell culture. Virology 248, 382-93.

[17]. Colina, F., Juca, N. T., Moreno, E., Ballestin, C., Farina, J., Nevado, M., Lumbreras, C., and Gomez-Sanz, R. (1995): Histological diagnosis of cytomegalovirus hepatitis in liver allografts. J ClinPathol 48, 351-7.

[18]. Compton, J. (1991): Nucleic acid sequence-based amplification. Nature 350, 91-2.

[19]. Contreras A., Mardirossian A., Slots J.(2001) Herpes virus in HIV-Periodontitis. J Clin Periodontal 28(1), 96-102.

[20]. Couchoud, C., Cucherat, M., Haugh, M., and Pouteil-Noble, C. (1998): Cytomegalovirus prophylaxis with antiviral agents in solid organ transplantation: a meta-analysis. Transplantation 65, 641-7.

[21]. Crumpacker, C. S. (1992): Mechanism of action of foscarnet against viral polymerases. Am J Med 92, 3S-7S

[22]. Crumpacker, C. S. (1996): Ganciclovir. N Engl J Med 335, 721-9.

[23]. Daly, J. S., Kopasz, A., Anandakrishnan, R., Robins, T., Mehta, S., Halvorsen, M., and Katz, E. (2002): Preemptive strategy for ganciclovir administration against cytomegalovirus in liver transplantation recipients. Am J Transplant 2, 955-8

[24]. Depto, A. S., and Stenberg, R. M. (1989): Regulated expression of the human cytomegalovirus pp65 gene: octamer sequence in the promoter is required for activation by viral gene products. J Virol 63, 1232-8.

[25]. Drew, W. L. (2000): Ganciclovir resistance: a matter of time and titre. Lancet 356, 609-10.

[26]. Einsele, H., Vallbracht, A., Jahn, G., Kandolf, R., and Muller, C. A. (1989): Hybridization techniques provide improved sensitivity for HCMV detection and allow quantitation of the virus in clinical samples. J Virol Methods 26, 91-104.

[27]. Emery, V. C. (1999): Viral dynamics during active cytomegalovirus infection and pathology. Intervirology $42,405-11$. 
[28]. Erice, A. (1999): Resistance of human cytomegalovirus to antiviral drugs. ClinMicrobiol Rev 12, 286-97.

[29]. Espy, M. J., Paya, C. V., Holley, K. E., Ludwig, J., Hermans, P. F., Wiesner, R. H., Krom, R. A., and Smith, T. F. (1991): Diagnosis of cytomegalovirus hepatitis by histopathology and in situ hybridization in liver transplantation. DiagnMicrobiol Infect Dis 14, 293-6.

[30]. Evans, P. C., Gray, J. J., Wreghitt, T. G., Marcus, R. E., and Alexander, G. J. (1999): Comparison of three PCR techniques for detecting cytomegalovirus (CMV) DNA in serum, detection of early antigen fluorescent foci and culture for the diagnosis of CMV infection. J Med Microbiol 48, 1029-35.

[31]. Gaeta, A., Nazzari, C., Angeletti, S., Lazzarini, M., Mazzei, E., and Mancini, C. (1997): Monitoring for cytomegalovirus infection in organ transplant recipients: analysis of pp65 antigen, DNA and late mRNA in peripheral blood leukocytes. J Med Virol 53, 189-95.

[32]. Griffiths, P. D., and Emery, V. C. (1997): Cytomegalovirus, pp. 445-470. In D. D. Richman, R. J. Whitley, and F. G. Hayden (Eds): Clinical virology, Churchill Livingstone.Griscelli, F., Barrois, M., Chauvin, S., Lastere, S., Bellet, D., and Bourhis, J. H. (2001): Quantification of human cytomegalovirus DNA in bone marrow transplant recipients by real-time PCR. J ClinMicrobiol 39, 4362-9.

[33]. Gerna, G., Baldanti, F., Lilleri, D., Parea, M., Torsellini, M., Castiglioni, B., Vitulo, P., Pellegrini, C., Vigano, M., Grossi, P., and Revello, M. G. (2003): Human cytomegalovirus pp67 mRNAemia versus pp65 antigenemia for guiding pre-emptive therapy in heart and lung transplant recipients: a prospective, randomized, controlled, open-label trial. Transplantation 75, $1012-9$.

[34]. Gerna, G., Percivalle, E., Baldanti, F., Sozzani, S., Lanzarini, P., Genini, E., Lilleri, D., and Revello, M. G. (2000): Human cytomegalovirus replicates abortively in polymorphonuclear leukocytes after transfer from infected endothelial cells via transient microfusion events. J Virol 74, 5629-38.

[35]. Gerna, G., Percivalle, E., Torsellini, M., and Revello, M. G. (1998): Standardization of the human cytomegalovirus antigenemia assay by means of in vitro-generated pp65-positive peripheral blood polymorphonuclear leukocytes. J ClinMicrobiol $36,3585-9$.

[36]. Gerna, G., Revello, M. G., Percivalle, E., and Morini, F. (1992): Comparison of different immunostaining techniques and monoclonal antibodies to the lower matrix phosphoprotein (pp65) for optimal quantitation of human cytomegalovirus antigenemia. J ClinMicrobiol 30, 1232-7.

[37]. Gleaves, C. A., Smith, T. F., Shuster, E. A., and Pearson, G. R. (1984): Rapid detection of cytomegalovirus in MRC-5 cells inoculated with urine specimens by using low-speed centrifugation and monoclonal antibody to an early antigen. J ClinMicrobiol $19,917-9$.

[38]. Goossens, V. J., Blok, M. J., Christiaans, M. H., van Hooff, J. P., Sillekens, P., Hockerstedt, K., Lautenschlager, I., Middeldorp, J. M., and Bruggeman, C. A. (1999): Diagnostic value of nucleic-acid-sequence- based amplification for the detection of cytomegalovirus infection in renal and liver transplant recipients. Intervirology 42, 373-81.

[39]. Gratacap-Cavallier, B., Bonadona, A., Berthier, R., Brambilla, E., Seigneurin, J. M., and Lorimier, P. (2003): A simplified cytomegalovirus pp65 antigenemia assay procedure. J ClinVirol 28, 317-22.

[40]. Grefte, J. M., van der Gun, B. T., Schmolke, S., van der Giessen, M., van Son, W. J., Plachter, B., Jahn, G., and The, T. H. (1992): The lower matrix protein pp65 is the principal viral antigen present in peripheral blood leukocytes during an active cytomegalovirus infection. J Gen Virol 73 (11), 2923-32.

[41]. Greijer, A. E., Adriaanse, H. M., Dekkers, C. A., and Middeldorp, J. M. (2002): Multiplex real-time NASBA for monitoring expression dynamics of human cytomegalovirus encoded IE1 and pp67 RNA. J ClinVirol 24, 57-66.

[42]. Grossi, P., Kusne, S., Rinaldo, C., St George, K., Magnone, M., Rakela, J., Fung, J., and Starzl, T. E. (1996): Guidance of ganciclovir therapy with pp65 antigenemia in cytomegalovirus- free recipients of livers from seropositive donors. Transplantation 61, 1659-60.

[43]. Hadaya, K., Wunderli, W., Deffernez, C., Martin, P. Y., Mentha, G., Binet, I., Perrin, L., and Kaiser, L. (2003): Monitoring of cytomegalovirus infection in solid-organ transplant recipients by an ultrasensitive plasma PCR assay. J ClinMicrobiol 41, 375764.

[44]. Halwachs-Baumann, G., Wilders-Truschnig, M., Desoye, G., Hahn, T., Kiesel, L., Klingel, K., Rieger, P., Jahn, G., and Sinzger, C. (1998): Human trophoblast cells are permissive to the complete replicative cycle of human cytomegalovirus. J Virol 72 , 7598-602.

[45]. Hanson, M. N., Preheim, L. C., Chou, S., Talarico, C. L., Biron, K. K., and Erice, A. (1995): Novel mutation in the UL97 gene of a clinical cytomegalovirus strain conferring resistance to ganciclovir. Antimicrob Agents Chemother 39, $1204-5$.

[46]. Hassan-Walker, A. F., Kidd, I. M., Sabin, C., Sweny, P., Griffiths, P. D., and Emery, V. C. (1999): Quantity of human cytomegalovirus (CMV) DNAemia as a risk factor for CMV disease in renal allograft recipients: relationship with donor/recipient CMV serostatus, receipt of augmented methylprednisolone and antithymocyte globulin (ATG). J Med Viro 158, $182-7$.

[47]. Hemmings, D. G., Kilani, R., Nykiforuk, C., Preiksaitis, J., and Guilbert, L. J. (1998): Permissive cytomegalovirus infection of primary villous term and first trimester trophoblasts. J Virol 72, 4970-9.

[48]. Ho, M. (1990): Epidemiology of cytomegalovirus infections. Rev Infect Dis 12 Suppl 7, S701-10.

[49]. Ho, M., Suwansirikul, S., Dowling, J. N., Youngblood, L. A. and Armstrong J. A. (1975) The transplanted kidney as a source of CMV infection. N. Engl J. Med. 293 (22): 1109-1112.

[50]. Ho, S. K., Li, F. K., Lai, K. N., and Chan, T. M. (2000): Comparison of the CMV brite turbo assay and the digene hybrid capture CMV DNA (Version 2.0) assay for quantitation of cytomegalovirus in renal transplant recipients. J ClinMicrobiol 38, 3743-5.

[51]. Ho, S. K., Lo, C. Y., Cheng, I. K., and Chan, T. M. (1998): Rapid cytomegalovirus pp65 antigenemia assay by direct erythrocyte lysis and immunofluorescence staining. J ClinMicrobiol 36, 638-40.

[52]. Humar, A., Gregson, D., Caliendo, A. M., McGeer, A., Malkan, G., Krajden, M., Corey, P., Greig, P., Walmsley, S., Levy, G., and Mazzulli, T. (1999): Clinical utility of quantitative cytomegalovirus viral load determination for predicting cytomegalovirus disease in liver transplant recipients. Transplantation 68, 1305-11.

[53]. Isada, C. M., Yen-Lieberman, B., Lurain, N. S., Schilz, R., Kohn, D., Lon gworth, D. L., Taege, A. J., Mossad, S. B., Maurer, J., Flechner, S. M., Mawhorter, S. D., Braun, W., Gordon, S. M., Schmitt, S. K., Goldman, M., Long, J., Haug, M., and Avery, R. K. (2002): Clinical characteristics of 13 solid organ transplant recipients with ganciclovirresistant cytomegalovirus infection. Transpl Infect Dis 4, 189-94.

[54]. Jabs, D. A., Martin, B. K., Forman, M. S., Dunn, J. P., Davis, J. L., Weinberg, D. V., Biron, K. K., and Baldanti, F. (2001): Mutations conferring ganciclovir resistance in a cohort of patients with acquired immunodeficiency syndrome and cytomegalovirus retinitis. J Infect Dis 183, 333-337.

[55]. Kim, C. K., Song, J. H., Kim, S. M., Peck, K. R., Oh, W., Huh, W., Kim, Y. G., Kim, S. J., Joh, J. W., Lee, N. Y., Park, C. G., Hwang, E. S., Cha, C. Y., and Oh, H. Y. (2003): Clinical usefulness of human cytomegalovirus antigenemia assay after kidney transplantation. Transplantation 75, 2151-5. 
[56]. Klemola E., Von Robert E., Henley G. (1997) Infectious mononucleosis like diseases with negative hetrophile agglutination test. Clinical features in relation to Epstein Barr virus and Cytomegalovirus antibiotics, J. Infect Dis 121: 608-611.

[57]. Koichi Yamanishi; Arvin, Ann M.; Gabriella Campadelli-Fiume; Edward Mocarski; Moore, Patrick; Roizman, Bernard; Whitley, Richard (2007). Human herpesviruses: biology, therapy, and immunoprophylaxis. Cambridge, UK: Cambridge University Press.

[58]. Kusne, S., Grossi, P., Irish, W., St George, K., Rinaldo, C., Rakela, J., and Fung, J. (1999): Cytomegalovirus PP65 antigenemia monitoring as a guide for preemptive therapy: a cost effective strategy for prevention of cytomegalovirus disease in adult liver transplant recipients. Transplantation 68, 1125-31.

[59]. Lake, K. D. (2003): New prophylactic treatment strategy for cytomegalovirus disease. Am J Health Syst Pharm 60, S13-6.

[60]. Lalezari, J. P., Drew, W. L., Glutzer, E., James, C., Miner, D., Flaherty, J., Fisher, P. E., Cundy, K., Hannigan, J., Martin, J. C., and et al. (1995): (S)-1-[3-hydroxy-2- (phosphonylmethoxy)propyl]cytosine (cidofovir): results of a phase I/II study of a novel antiviral nucleotide analogue. J Infect Dis 171, 788-96.

[61]. Landry, M. L., and Ferguson, D. (1993): Comparison of quantitative cytomegalovirus antigenemia assay with culture methods and correlation with clinical disease. J ClinMicrobiol 31, 2851-6.

[62]. Landry, M. L., Stanat, S., Biron, K., Brambilla, D., Britt, W., Jokela, J., Chou, S., Drew, W. L., Erice, A., Gilliam, B., Lurain, N., Manischewitz, J., Miner, R., Nokta, M., Reichelderfer, P., Spector, S., Weinberg, A., Yen-Lieberman, B., and Crumpacker, C. (2000): A standardized plaque reduction assay for determination of drug susceptibilities of cytomegalovirus clinical isolates. Antimicrob Agents Chemother 44, 688-92.

[63]. Lautenschlager, I., Suni, J., Ahonen, J., Gronhagen-Riska, C., Ruutu, P., Ruutu, T., and Tukiainen, P. (1989): Detection of cytomegalovirus by the early-antigen immunofluorescence test versus conventional tissue culture. Eur J ClinMicrobiol Infect Dis 8 , 610-3.

[64]. Lerner PI, Sampliner JE. (1977) Transfusion associated cytomegalovirus mononucleosis. Ann Surg 185, 406-10.

[65]. Limaye, A. P. (2002): Ganciclovir-resistant cytomegalovirus in organ transplant recipients. Clin Infect Dis 35, 866-72.

[66]. Littler E, Stuart A D, Chee M S.(1992): Human cytomegalovirus UL97 open reading frame encodes a protein that phosphorylates the antiviral nucleoside analogue ganciclovir. Nature358, 160-162.

[67]. Littler, E., Stuart, A. D., and Chee, M. S. (1992): Human cytomegalovirus UL97 open reading frame encodes a protein that phosphorylates the antiviral nucleoside analogue ganciclovir. Nature 358, 160-2.

[68]. Lowance, D., Neumayer, H. H., Legendre, C. M., Squifflet, J. P., Kovarik, J., Brennan, P. J., Norman, D., Mendez, R., Keating, M. R., Coggon, G. L., Crisp, A., and Lee, I. C. (1999): Valacyclovir for the prevention of cytomegalovirus disease after renal transplantation. International Valacyclovir Cytomegalovirus Prophylaxis Transplantation Study Group. N Engl J Med 340, 1462-70.

[69]. Lurain, N. S., and S. Chou.2010. Antiviral drug resistance of human cytomegalovirus.ClinMicrobiol Rev 23,689-712.

[70]. Lurain, N. S., Bhorade, S. M., Pursell, K. J., Avery, R. K., Yeldandi, V. V., Isada, C. M., Robert, E. S., Kohn, D. J., Arens, M. Q., Garrity, E. R., Taege, A. J., Mullen, M. G., Todd, K. M., Bremer, J. W., and Yen-Lieberman, B. (2002): Analysis and characterization of antiviral drug-resistant cytomegalovirus isolates from solid organ transplant recipients. J Infect Dis 186, 760-8.

[71]. Lurain, N. S., Spafford, L. E., and Thompson, K. D. (1994): Mutation in the UL97 open reading frame of human cytomegalovirus strains resistant to ganciclovir. J Virol 68, 4427-31.

[72]. Mazzulli, T., Drew, L. W., Yen-Lieberman, B., Jekic-McMullen, D., Kohn, D. J., Isada, C., Moussa, G., Chua, R., and Walmsley, S. (1999): Multicenter comparison of the digene hybrid capture CMV DNA assay (version 2.0), the pp65 antigenemia assay, and cell culture for detection of cytomegalovirus viremia. J ClinMicrobiol 37, 958-63.

[73]. McSharry, J. J., Lurain, N. S., Drusano, G. L., Landay, A. L., Notka, M., O'Gorman, M. R., Weinberg, A., Shapiro, H. M., Reichelderfer, P. S., and Crumpacker, C. S. (1998): Rapid ganciclovir susceptibility assay using flow cytometry for human cytomegalovirus clinical isolates. Antimicrob Agents Chemother 42, 2326-31.

[74]. Mendez, J. C., Sia, I. G., and Paya, C. V. (1999a): Human cytomegalovirus, pp. 361- 372. In E. H. Lennette, and T. F. Smith (Eds): Laboratory diagnosis of viral infections, Marcel Dekker, Inc., New York. Mendez, J. C., Sia, I. G., Tau, K. R., Espy, M. J., Smith, T. F., Chou, S., and Paya, C. V. (1999b): Novel mutation in the CMV UL97 gene associated with resistance to ganciclovir therapy. Transplantation 67, 755-7.

[75]. Merigan, T. C., Renlund, D. G., Keay, S., Bristow, M. R., Starnes, V., O'Connell, J. B., Resta, S., Dunn, D., Gamberg, P., Ratkovec, R. M., and et al. (1992): A controlled trial of ganciclovir to prevent cytomegalovirus disease after heart transplantation. N Engl J Med 326, 1182-6.

[76]. Mettenleiter, T. C. (2002): Herpesvirus assembly and egress. J Virol 76, 1537-47.

[77]. Michaelides, A., Facey, D., Spelman, D., Wesselingh, S., and Kotsimbos, T. (2003): HCMV DNA detection and quantitation in the plasma and PBL of lung transplant recipients: COBAS Amplicor HCMV monitor test versus in-house quantitative HCMV PCR. J ClinVirol 28, 111-20.

[78]. Mocarski, E. S., and Courcelle, C. T. (2001): Cytomegaloviruses and their replication, pp. 2629-2673. In D. M. Knipe, and P. M. Howley (Eds): Fields virology, Lippincott, Williams and Wilkins, Philadephia.

[79]. Mollison, L. C., Richards, M. J., Johnson, P. D., Hayes, K., Munckhof, W. J., Jones, R. M., Dabkowski, P. D., and Angus, P. W. (1993): High-dose oral acyclovir reduces the incidence of cytomegalovirus infection in liver transplant recipients. J Infect Dis $168,721-4$.

[80]. Monte, P. D., Lazzarotto, T., Ripalti, A., and Landini, M. P. (1996): Human cytomegalovirus infection: a complex diagnostic problem in which molecular biology has induced a rapid evolution. Intervirology 39, 193-203.

[81]. Mousavi-Jazi, M., Schloss, L., Wahren, B., and Brytting, M. (2003): Point mutations induced by foscarnet (PFA) in the human cytomegalovirus DNA polymerase. J ClinVirol 26, 301-6.

[82]. Musiani, M., Roda, A., Zerbini, M., Pasini, P., Gentilomi, G., Gallinella, G., and Venturoli, S. (1996): Chemiluminescent in situ hybridization for the detection of cytomegalovirus DNA. Am J Pathol 148, 1105-12.

[83]. Naraqi S. (1991) Cytomegalovirus. In: Belshe RB. ed. Textbook of human virology, 2nded, St. Luois: Mosby 1991, pp 889-924.

[84]. Nelson, P. N., Rawal, B. K., Boriskin, Y. S., Mathers, K. E., Powles, R. L., Steel, H. M., Tryhorn, Y. S., Butcher, P. D., and Booth, J. C. (1996): A polymerase chain reaction to detect a spliced late transcript of human cytomegalovirus in the blood of bone marrow transplant recipients. J Virol Methods 56, 139-48.

[85]. Noble, S., and Faulds, D. (1998): Ganciclovir. An update of its use in the prevention of cytomegalovirus infection and disease in transplant recipients.Drugs 56, 115-46.

[86]. Mocarski, E. S., Jr. (2002): Immunomodulation by cytomegaloviruses: manipulative strategies beyond evasion. Trends Microbiol $10,332-9$. 
[87]. Norris, S., Kosar, Y., Donaldson, N., Smith, H. M., Zolfino, T., O'Grady, J. G., Muiesan, P., Rela, M., and Heaton, N. (2002): Cytomegalovirus infection after liver transplantation: viral load as a guide to treating clinical infection. Transplantation 74, 527-31.

[88]. Oldenburg, N., Lam, K. M., Khan, M. A., Top, B., Tacken, N. M., McKie, A., Mikhail, G. W., Middeldorp, J. M., Wright, A., Banner, N. R., and Yacoub, M. (2000): Evaluation of human cytomegalovirus gene expression in thoracic organ transplant recipients using nucleic acid sequence-based amplification. Transplantation 70, 1209-15.

[89]. Parra B, Slots J. (1996): Detection of human viruse in periodontal pockets using polymerase chain reaction. Oral MicrobiolImmunol 11(5), 289-93.

[90]. Patel, R., and Paya, C. V. (1997): Infection in solid in solid organ transplant recipientsClinMicrobiol Rev10,86-124.

[91]. Patel, R., Snydman, D. R., Rubin, R. H., Ho, M., Pescovitz, M., Martin, M., and Paya, C. V. (1996): Cytomegalovirus prophylaxis in solid organ transplant recipients. Transplantation 61, 1279-89.

[92]. Paya, C. V., Hermans, P. E., Wiesner, R. H., Ludwig, J., Smith, T. F., Rakela, J., and Krom, R. A. (1989): Cytomegalovirus hepatitis in liver transplantation: prospective analysis of 93 consecutive orthotopic liver transplantations. J Infect Dis 160, 752-8.

[93]. Paya, C. V., Holley, K. E., Wiesner, R. H., Balasubramaniam, K., Smith, T. F., Espy, M. J., Ludwig, J., Batts, K. P., Hermans, P. E., and Krom, R. A. (1990): Early diagnosis of cytomegalovirus hepatitis in liver transplant recipients: role of immunostaining, DNA hybridization and culture of hepatic tissue. Hepatology 12, 119-26.

[94]. Paya, C., Humar, A., Dominguez, E., Washburn, K., Blumberg, E., Alexander, B., Freeman, R., Heaton, N., and Pescovitz, M. D. (2004): Efficacy and Safety of Valganciclovir vs. Oral Ganciclovir for Prevention of Cytomegalovirus Disease in Solid Organ Transplant Recipients. Am J Transplant 4, 611-20.

[95]. Pescovitz, M. D., Rabkin, J., Merion, R. M., Paya, C. V., Pirsch, J., Freeman, R. B., O'Grady, J., Robinson, C., To, Z., Wren, K., Banken, L., Buhles, W., and Brown, F. (2000): Valganciclovir results in improved oral absorption of gancyclovir in liver transplant recipients. Antimicrob Agents Chemother 44, 2811-5.

[96]. PorathA ,Mc Nutt R. A., Smiley L.M. (1990): Effectiveness and cost benefit of a proposedlivecytomegaloviruse vaccine in the prevention of the congenital disease. Rev Infect Dis 12(1), 31-40.

[97]. Razonable, R. R., Paya, C. V., and Smith, T. F. (2002b): Role of the laboratory in diagnosis and management of cytomegalovirus infection in hematopoietic stem cell and solid- organ transplant recipients. J ClinMicrobiol 40, 746-52.

[98]. Rosen, H. R., Benner, K. G., Flora, K. D., Rabkin, J. M., Orloff, S. L., Olyaei, A., and Chou, S. (1997): Development of ganciclovir resistance during treatment of primary cytomegalovirus infection after liver transplantation. Transplantation 63, 476-8.

[99]. Ryan KJ, Ray CG (2004). Sherris Medical Microbiology (4th ed.). McGraw Hill.pp. 556; 566-9.

[100]. Sagedal, S., Nordal, K. P., Hartmann, A., Midtvedt, K., Foss, A., Asberg, A., Degre, M., Fauchald, P., and Rollag, H. (2003): Pre-emptive therapy of CMVpp65 antigen positive renal transplant recipients with oral ganciclovir: a randomized, comparative study. Nephrol Dial Transplant 18, 1899-908.

[101]. Schafer, P., Tenschert, W., Gutensohn, K., and Laufs, R. (1997): Minimal effect of delayed sample processing on results of quantitative PCR for cytomegalovirus DNA in leukocytes compared to results of an antigenemia assay. J ClinMicrobiol 35, 741-4.

[102]. Sia, I. G., and Patel, R. (2000): New strategies for prevention and therapy of cytomegalovirus infection and disease in solid-organ transplant recipients.ClinMicrobiol Rev 13, 83-121.

[103]. Sinzger, C., and Jahn, G. (1996): Human cytomegalovirus cell tropism and pathogenesis. Intervirology 39, 302-19.

[104]. Snoeck, R., Sakuma, T., De Clercq, E., Rosenberg, I., and Holy, A. (1988): (S)-1-(3- hydroxy-2phosphonylmethoxypropyl)cytosine, a potent and selective inhibitor of human cytomegalovirus replication. Antimicrob Agents Chemother 32, 1839-44.

[105]. Speich, R., Thurnheer, R., Gaspert, A., Weder, W., and Boehler, A. (1999): Efficacy and cost effectiveness of oral ganciclovir in the prevention of cytomegalovirus disease after lung transplantation. Transplantation 67, 315-20.

[106]. Sullivan, V., Talarico, C. L., Stanat, S. C., Davis, M., Coen, D. M., and Biron, K. K. (1992): A protein kinase homologue controls phosphorylation of ganciclovir in human cytomegalovirus-infected cells. Nature 358, 162-4.

[107]. Talarico, C. L., Burnette, T. C., Miller, W. H., Smith, S. L., Davis, M. G., Stanat, S. C., Ng, T. I., He, Z., Coen, D. M., Roizman, B., and Biron, K. K. (1999): Acyclovir is phosphorylated by the human cytomegalovirus UL97 protein. Antimicrob Agents Chemother 43, 1941-6.

[108]. Tanabe, K., Tokumoto, T., Ishikawa, N., Koyama, I., Takahashi, K., Fuchinoue, S., Kawai, T., Koga, S., Yagisawa, T., Toma, H., Ota, K., and Nakajima, H. (1997): Comparative study of cytomegalovirus (CMV) antigenemia assay, polymerase chain reaction, serology, and shell vial assay in the early diagnosis and monitoring of CMV infection after renal transplantation. Transplantation 64, 1721-5.

[109]. The, T. H., van den Berg, A. P., Harmsen, M. C., van der Bij, W., and van Son, W. J. (1995): The cytomegalovirus antigenemia assay: a plea for standardization. Scand J Infect Dis Suppl 99, 25-9.

[110]. Van den Berg, A. P., Klompmaker, I. J., Haagsma, E. B., Scholten-Sampson, A., Bijleveld, C. M., Schirm, J., van der Giessen, M., Slooff, M. J., and The, T. H. (1991): Antigenemia in the diagnosis and monitoring of active cytomegalovirus infection after liver transplantation. J Infect Dis 164, 265-70.

[111]. Van der Bij, W., Schirm, J., Torensma, R., van Son, W. J., Tegzess, A. M., and The, T. H. (1988): Comparison between viremia and antigenemia for detection of cytomegalovirus in blood. J ClinMicrobiol 26, 2531-5.

[112]. Verschuuren, E. A., Harmsen, M. C., Limburg, P. C., van Der Bij, W., van Den Berg, A. P., Kas-Deelen, A. M., Meedendorp, B., van Son, W. J., and The, T. H. (1999): Towards standardization of the human cytomegalovirus antigenemia assay. Intervirology $42,382-9$.

[113]. Wang, X., Huong, S. M., Chiu, M. L., Raab-Traub, N., and Huang, E. S. (2003): Epidermal growth factor receptor is a cellular receptor for human cytomegalovirus. Nature 424, 456-61.

[114]. Weill, D., Lock, B. J., Wewers, D. L., Young, K. R., Zorn, G. L., Early, L., Kirklin, J. K., and McGiffin, D. C. (2003): Combination prophylaxis with ganciclovir and cytomegalovirus (CMV) immune globulin after lung transplantation: effective CMV prevention following daclizumab induction. Am J Transplant 3, 492-6.

[115]. Weller, S., Blum, M. R., Doucette, M., Burnette, T., Cederberg, D. M., de Miranda, P., and Smiley, M. L. (1993): Pharmacokinetics of the acyclovir pro-drug valaciclovir after escalating single- and multiple-dose administration to normal volunteers. ClinPharmacolTher 54, 595-605.

[116]. Winston, D. J., and Busuttil, R. W. (2004): Randomized controlled trial of sequential intravenous and oral ganciclovir versus prolonged intravenous ganciclovir for long-term prophylaxis of cytomegalovirus disease in high-risk cytomegalovirus-seronegative liver transplant recipients with cytomegalovirus-seropositive donors. Transplantation 77, 305-8.

[117]. Winston, D. J., Wirin, D., Shaked, A., and Busuttil, R. W. (1995): Randomised comparison of ganciclovir and high-dose acyclovir for long-term cytomegalovirus prophylaxis in liver-transplant recipients. Lancet 346, 69-74. 
[118]. Wirgart, B. Z., Claesson, K., Eriksson, B. M., Brundin, M., Tufveson, G., Totterman, T., and Grillner, L. (1996): Cytomegalovirus (CMV) DNA amplification from plasma compared with CMV pp65 antigen (ppUL83) detection in leukocytes for early diagnosis of symptomatic CMV infection in kidney transplant patients. ClinDiagnVirol 7, 99- 110.

[119]. Witt, D. J., Kemper, M., Stead, A., Sillekens, P., Ginocchio, C. C., Espy, M. J., Paya, C. V., Smith, T. F., Roeles, F., and Caliendo, A. M. (2000): Analytical performance and clinical utility of a nucleic acid sequence-based amplification assay for detection of cytomegalovirus infection. J ClinMicrobiol 38, 3994-9.

[120]. Wolf, D. G., Smith, I. L., Lee, D. J., Freeman, W. R., Flores-Aguilar, M., and Spector, S. A. (1995): Mutations in human cytomegalovirus UL97 gene confer clinical resistance to ganciclovir and can be detected directly in patient plasma. J Clin Invest 95 , 257-63.

[121]. Yango, A., Morrissey, P., Zanabli, A., Beaulieu, J., Shemin, D., Dworkin, L., Monaco, A., and Gohh, R. (2003): Comparative study of prophylactic oral ganciclovir and valacyclovir in high-risk kidney transplant recipients. Nephrol Dial Transplant 18, 80913.

[122]. Zamora, M. R. (2001): Use of cytomegalovirus immune globulin and ganciclovir for the prevention of cytomegalovirus disease in lung transplantation. Transpl Infect Dis 3 Suppl 2, 49-56. 